Counsellia: Jurnal Bimbingan dan Konseling

Volume 11 (2) 167 - 179 November 2021

ISSN: 2088-3072 (Print) / 2477-5886 (Online)

DOI: 10.25273/counsellia.v11i2.10101

Available online at: http://e-journal.unipma.ac.id/index.php/JBK

\title{
ANALISIS PERAN TEMAN SEBAYA DALAM PENGAMBILAN KEPUTUSAN KARIER
}

\author{
Insan Suwanto $\square,{ }^{1}$ Dian Mayasari ${ }^{2}$, Nurul Wulan Dhari ${ }^{3}$ \\ ${ }^{1}$ Bimbingan Konseling, STKIP Singkawang, Singkawang \\ email: insansuwanto@gmail.com \\ ${ }^{2}$ Bimbingan Konseling, STKIP Singkawang, Singkawang \\ email: diansingkawang@ gmail.com \\ ${ }^{3}$ Bimbingan Konseling, STKIP Singkawang, Singkawang \\ email: $\square \underline{\text { dhwulan7@gmail.com }}$
}

\begin{abstract}
This study aims to: 1) describe the role shown by peer groups in influencing career decisions; 2) identify the causal factors that influence career decision making. This study uses a qualitative approach to know in-depth the role of peers in students' career decision-making. In collecting data, the researcher conducted structured interviews with the six students of class XII. Interviews were conducted using peer role interview guidelines and career decision-making factors that have been tested through construction validity tests (expert judgment). Then, the research data were analyzed using themodel Miles and Huberman consisting of data reduction, data display, and conclusion drawing/verification. The results showed: 1) the role of peer groups was seen in aspects of social, moral and emotional support; freedom of opinion, action or self-identity. While the aspects as agents of socialization and developing skills are not found in peers. 2) Environmental conditions are very influential in making career decisions. Meanwhile, the learning factor is not very influential in making career decisions. Based on the results of the study, peers should be able to choose friends who can be used as role models and guidance and counseling teachers can facilitate the formation of peer groups that discuss career issues so that students can independently make career decisions.
\end{abstract}

\footnotetext{
Abstrak. Penelitian ini bertujuan untuk: 1) mendeskripsikan peran yang ditunjukkan oleh kelompok teman sebaya dalam mempengaruhi keputusan karier; 2) mengidentifikasi faktor-faktor penyebab yang mempengaruhi pengambilan keputusan karier. Penelitian ini menggunakan pendekatan kualitatif dengan tujuan untuk mengetahui secara mendalam terkait peran teman sebaya dalam pengambilan keputusan karier siswa. Dalam mengumpulkan data, peneliti melakukan wawancara terstruktur kepada keenam orang siswa kelas XII. Wawancara yang dilakukan dengan pedoman wawancara peran teman sebaya dan faktor pengambilan keputusan karier yang telah diuji melalui uji validitas konstruksi (judgement experts). Kemudian, data hasil penelitian dianalisis menggunakan model Miles and Huberman yang terdiri dari data reduction, data display, dan conclusion drawing/verification. Hasil penelitian menunjukkan: 1) peran kelompok teman sebaya terlihat pada aspek dukungan sosial, moral dan emosional; kebebasan berpendapat, bertindak atau menemukan identitas diri. Sedangkan aspek sebagai agen sosialisasi dan mengembangkan keterampilan tidak terlalu ditemukan pada teman sebaya. 2) Faktor kondisi lingkungan sangat berpengaruh dalam pengambilan keputusan karier. Sedangkan untuk faktor belajar tidak terlalu berpengaruh dalam pengambilan keputusan karier.
} 
Berdasarkan hasil penelitian, hendaknya teman sebaya bisa memilih teman yang dapat dijadikan sebagai role model dan Guru BK dapat memfasilitasi pembentukan kelompok teman sebaya yang membahas terkait permasalahan karier agar siswa bisa secara mandiri mengambil keputusan karier.

Keywords: Teman Sebaya, Keputusan Karier

Received ; 18-11-2021 Accepted ; 22-11-2021 Published; 29-11-2021

Citation: Dhari, N. W., Mayasari, D., \& Suwanto, I. (2021). Pentingnya Kelompok Teman Sebaya Dalam Pengambilan Keputusan Karier. Counsellia: Jurnal Bimbingan dan Konseling, 11(1), 167 - 179. Doi.org/10.25273/counsellia.v11i2.10101

\section{(C) EY-NC-SA}

Copyright (C2021 Counsellia: Bimbingan dan Konseling

Published by Universitas PGRI Madiun. This work is licensed under the Creative Commons Attribution-NonCommercialShareAlike 4.0 International License

\section{PENDAHULUAN}

Pendidikan merupakan proses yang berlangsung seumur hidup, yaitu sejak lahir hingga akhir hayat. Pendidikan harus diselenggarakan dengan sistem terbuka yang memungkinkan fleksibilitas pilihan dan waktu penyelesaian program secara lintas satuan dan jalur pendidikan (Undang-Undang Republik Indonesia Nomor 22 Tahun 2015 Tentang Rencana Strategis Kementerian Pendidikan dan Kebudayaan). Hal ini juga dikemukakan oleh Suhartono (2009) menyatakan bahwa pendidikan adalah segala kegiatan pembelajaran yang berlangsung sepanjang zaman dalam segala situasi kegiatan kehidupan. Sehingga, pendidikan memiliki peranan penting dalam kehidupan seseorang untuk bekal dalam mengambil keputusan yang akan datang, salah satunya adalah keputusan karier seseorang.

Karier merupakan suatu hal terpenting dalam kehidupan seseorang dan diperoleh berdasarkan hasil pengalaman hidupnya. Karier akan menjadi tepat apabila bisa mengambil keputusan yang tepat. Oleh karenanya, seseorang akan bekerja dengan baik dan senang hati apabila segala hal yang dikerjakannya sesuai dengan keadaan dirinya, kemampuannya, dan minatnya. Sebaliknya, apabila seseorang tidak merasa sesuai dengan apa yang ada dalam dirinya maka ia akan kurang bersemangat dalam bekerja. Maka dari itu, perlu adanya kesesuaian antara pekerjaan atau jabatan dengan minat dan bakatnya serta kepribadiannya (Walgito, 2010).

Karier menurut Kamus Besar Bahasa Indonesia (KBBI) adalah perkembangan dan kemajuan baik pada kehidupan, pekerjaan, atau jabatan seseorang. Sebagaimana yang dikemukakan oleh Krumboltz (Prastya, 2016) bahwa karier seseorang berasal dari interaksi pribadi dan lingkungan yang diperoleh dari hasil belajar. Seseorang tersebut sepenuhnya rasional akan mengambil keputusan berdasarkan pengalaman belajarnya yang dipengaruhi oleh orang tua, guru, hobi, atau ketertarikan yang menggerakkan individu untuk mengenal, serta mengeksplorasi pekerjaan atau studi lanjut yang diasosiasikan dengan elemen dalam hidupnya.

Seligman (Marliyah et al., 2004) juga menyatakan bahwa karier seseorang dibangun dan dikembangkan sejak masa sekolah dan juga karier merupakan suatu citacita yang diinginkan, baik dibidang pendidikan, pekerjaan, maupun suatu profesi tertentu. Karier seseorang tidak bisa ditentukan secara langsung saat itu juga namun perlu adanya proses disepanjang hidupnya. Proses ini bisa terjadi antara individu dengan lingkungan. 
Mengenai karier, banyak permasalahan yang dihadapi anak-anak usia remaja. Mereka cenderung masih mengalami kebingungan, ketidakpastian dan stress dalam mengambil keputusan. Supriatna \& Budiman (2010) menyatakan permasalahan karier yang dirasakan siswa adalah siswa kurang memahami cara memilih program studi yang cocok dengan kemampuan dan minat, siswa tidak memiliki informasi tentang dunia kerja yang cukup, siswa masih bingung memilih pekerjaan atau studi lanjut, siswa masih kurang mampu memilih pekerjaan yang sesuai dengan kemampuan dan minat, dan siswa merasa cemas untuk mendapatkan pekerjaan setelah tamat sekolah. Sama halnya dengan yang dialami oleh siswa-siswi di Madrasah Aliyah Negeri (MAN) Singkawang. Misalnya, seperti siswa masih kurang mampu dalam menetukan pilihan karier yang cocok dengan dirinya, bingung akan pilihan karier yang sesuai dengan minatnya, kurangnya informasi mengenai karier dan kurangnya dukungan dalam pilihan karier yang dipilih.

Maka dari itu, kemampuan siswa dalam mempersiapkan kariernya masih sangat rendah dan menimbulkan berbagai permasalahan seperti di atas. Hal ini berakibat pada proses pengambilan keputusan karier. Proses yang dialami oleh siswa tersebut ialah berorientasi pada hal yang berhubungan dengan bagaimana seseorang membuat keputusan karier di sekitar mereka (Istifarani, 2016). Sehingga, dengan adanya pengambilan keputusan terkait karier maka siswa akan belajar untuk memilih atau memutuskan suatu permasalahan terkait kariernya di masa depan.

Permasalahan-permasalahan yang dialami siswa juga bisa teratasi tergantung dari representasi seseorang dimasa depan. Apabila siswa berorientasi masa depan maka siswa bisa mengantisipasi peristiwa karier dimasa depan dan hasil, menghubungkan kepada mereka makna pribadi dan menghubungkan standar pribadi untuk peristiwa ini (Imbellone \& Laghi, 2016). Selain itu, siswa Madrasah Aliyah Negeri (MAN) dalam menentukan pilihan kariernya memerlukan beberapa pertimbangan, seperti pemahaman pekerjaan yang cocok dimasa depan, pemahaman kemampuan atau bakat yang sesuai, faktor penghambat dan pendukung dalam memilih karier sebelum mengambil keputusan. Pengambilan keputusan karier yang ditandai dengan adanya penetapan pilihan karier adalah persoalan penting bagi siswa Madrasah Aliyah Negeri (MAN), karena akan menentukan arah kariernya pada masa yang akan datang.

Namun, dari semua pertimbangan-pertimbangan tersebut pengambilan keputusan karier dipengaruhi oleh beberapa faktor, salah satunya teman sebaya. Hal ini diperjelas oleh Holland (Amsanah, 2018) karier akan dipengaruhi oleh berbagai faktor, seperti budaya, teman bergaul, orang tua, orang dewasa yang dianggap memiliki peranan penting. Melalui teman sebaya, siswa saling berinteraksi dan bertukar pendapat mengenai permasalahan karier di masa mendatang. Selain itu, siswa juga mengumpulkan informasi karier dari berbagai sumber, dan memanfaatkan informasi karier yang telah diperoleh (Suwanto, 2018).

Sama halnya dengan hasil penelitian Aminnurrohim et al., (2014), menyatakan bahwa faktor penghambat eksternal salah satunya ialah teman sebaya yang berpengaruh tinggi dalam menentukan perencanaan karier siswa yaitu kategori tinggi sebesar $68 \%$. Selain itu, berdasarkan hasil penelitian Zulfa et al., (2018) mengatakan bahwa teman sebaya dapat mempengaruhi minat siswa dalam melanjutkan studi ke perguruan tinggi. Pengaruh teman sebaya merupakan salah satu faktor eksternal dimana teman sebaya memberikan dorongan berupa minat dalam memilih karier di masa depan.

Teman sebaya akan mempengaruhi pilihan-pilihan karier yang akan diambil oleh siswa berupa peran yang ditunjukkannya. Kelompok teman sebaya dapat menjadi sumber dukungan ketika seseorang membutuhkan arahan dalam penentuan keputusan karier 
dibandingkan dengan orang tua (Kristiono, 2018). Teman sebaya merupakan orang dengan tingkat usia atau tingkat kematangan yang kurang lebih sama (Santrock, 2007).

Namun, ada beberapa aspek yang perlu diperhatikan. Hurlock (2006) berpendapat sikap teman sebaya yang berorientasi sekolah atau bekerja sangat mempengaruhi keputusan yang diambil seseorang akan masa depannya. Apabila teman sebaya yang lebih berorientasi kepada sekolah (melanjutkan pendidikan ke perguruan tinggi), maka siswa tersebut akan berminat melanjutkan pendidikannya ke perguruan tinggi begitupun sebaliknya.

Berdasarkan wawancara prapenelitian yang dilakukan dengan guru BK, diperoleh informasi bahwa beberapa siswa di Madrasah Aliyah Negeri (MAN) Singkawang lebih mempercayai teman sebaya dibanding orang tua ketika mereka sedang kebingungan dalam menentukan pilihan karier ataupun studi lanjutan. Mereka cenderung lebih mempercayai informasi yang disampaikan oleh teman sebaya. Apabila teman memberikan saran yang cocok dengan dirinya maka siswa-siswi akan mengikutinya, bahkan jika pilihan awal karier yang akan dipilih namun teman berpendapat hal itu tidak bagus maka mereka tidak akan memilihnya. Sehingga, bagi beberapa siswa menganggap teman sebaya seperti teman bercerita ketika orang tua tidak bisa memberikan pilihan atau saran yang pasti bagi kelanjutan karier.

Berdasarkan penjelasan di atas peran teman sebaya sangat penting dan berpengaruh dalam menentukan kehidupan karier siswa. Peran teman sebaya bisa berbentuk positif ataupun negatif, tergantung dari teman yang dipercayai. Peran tersebut seperti sebagai sahabat; sumber dukungan berupa mendukung ketika kurang arahan dalam penentuan keputusan karir apabila orangtua kurang memberikan arahan dan lain sebagainya serta fungsi kasih sayang yaitu berupa dukungan untuk pandangan ke depan dalam pengambilan keputusan karirnya seperti memilih menentukan pendidikan lanjut atau kuliah bahkan kerja untuk kerja dimana atau malah menciptakan lapangan pekerjaan sendiri (Kristiono, 2018). Oleh karena itu, penelitian ini berfokus pada peran kelompok teman sebaya dalam memberikan kontribusinya saat mengambil keputusan karier siswa. Selain itu, penelitian ini juga berfokus pada faktor yang berpengaruh dalam pengambilan keputusan karier.

Penelitian ini bertujuan untuk mendeskripsikan peran yang ditunjukkan oleh kelompok teman sebaya dalam mempengaruhi keputusan karier. Namun, dari berbagai peran tersebut peran mana yang telah mempengaruhi keputusan karier. Penelitian ini juga bertujuan untuk mengidentifikasi faktor-faktor penyebab yang mempengaruhi pengambilan keputusan karier siswa. Sehingga, baik dari siswa maupun guru BK bisa mengetahui faktor apa yang mempengaruhi keputusan karier yang telah dibuat.

\section{METODE PENELITIAN \\ Rancangan Penelitian}

Penelitian ini adalah penelitian deskriptif kualitatif. Penelitian deskriptif kualitatif (Sukmadinata, 2011) ditujukan untuk mendeskripsikan dan menggambarkan fenomenafenomena yang ada, baik bersifat alamiah maupun rekayasa manusia, yang lebih memperhatikan mengenai karakteristik, kualitas, keterkaitan antar kegiatan. Menurut Moleong (2016), penelitian kualitatif adalah penelitian yang bermaksud untuk memahami fenomena tentang apa yang dialami oleh subyek penelitian misalnya, perilaku, persepsi, motivasi, tindakan dan lain-lain, secara holistik dan dengan cara deskripsi dalam bentuk kata-kata dan bahasa, pada suatu konteks khusus yang alamiah dan dengan memanfaatkan berbagai metode alamiah. Melalui penelitian kualitatif, peneliti berusaha untuk memahami dan mendeskripsikan suatu fenomena yang sedang terjadi di lapangan yaitu 
peran kelompok teman sebaya dalam pengambilan keputusan karier. Peneliti ikut berpatisipasi dan berinteraksi secara langsung dengan subyek penelitian untuk memperoleh berbagai informasi yang diperlukan. Sehingga, dari berbagai informasi tersebut dapat dijelaskan dan disimpulkan secara deskripsi dalam bentuk kata-kata.

\section{Sumber Data}

Subjek penelitian dipilih oleh peneliti dengan menggunakan teknik purposive sampling. Purposive sampling adalah teknik pengambilan sampel sumber data dengan pertimbangan tertentu (Sugiyono, 2014). Dalam penelitian ini subjek penelitian yang digunakan ialah siswa kelas XII MAN Kota Singkawang yang berjumlah 6 orang, dimana diseleksi sesuai dengan beberapa kriteria. Adapun kriteria yang menjadi subjek penelitian ini ialah:

1. Siswa yang mengalami permasalahan dalam karier.

2. Siswa yang belum bisa mengambil keputusan karier secara mandiri.

3. Siswa yang merasa lebih percaya dengan teman sebayanya dalam permasalahan karier.

\section{Teknik Pengumpulan Data}

Teknik pengumpulan data yang digunakan dalam penelitian ini ialah teknik wawancara. Menurut Esterberg (Sugiyono, 2014) wawancara adalah pertemuan dua orang untuk bertukar informasi dan ide melalui tanya jawab, sehingga dapat dikonstruksikan makna dalam suatu topik tertentu. Melalui teknik wawancara peneliti bisa mengetahui secara mendalam terkait peran teman sebaya dan faktor pengambilan keputusan karier ketika peneliti tidak bisa menemukannya dari observasi saja. Namun, selama melakukan penelitian peneliti menggunakan teknik wawancara terstruktur dikarenakan ingin memberikan batasan pada hasil wawancara yang diperoleh dan untuk menghindari jawaban yang tidak sesuai dengan apa yang ingin ditanyakan oleh peneliti. Selama mengumpulkan data, peneliti menggunakan pedoman wawancara yang telah diuji menggunakan uji validitas konstruksi (judgement experts).

\section{Teknik Analisis Data}

Dalam penelitian ini peneliti menggunakan teknik analisis data model Miles and Huberman. Aktivitas dalam analisis data, yaitu data reduction, data display, dan conclusion drawing/verification (Sugiyono, 2017). Pertama, di tahap data reduction (reduksi data) peneliti mereduksi data dengan merangkum dan memfokuskan hasil wawancara dengan jawaban yang sesuai pertanyaan serta menghapus jawaban yang tidak sesuai dengan pertanyaan selama wawancara. Dengan demikian, data yang telah direduksi akan memberikan gambaran yang lebih jelas, dan mempermudah peneliti untuk mencarinya bila diperlukan.

Kedua, ditahap data display (penyajian data) adalah menyajikan data yang telah direduksi. Penyajian data ini peneliti sajikan dalam bentuk tabel. Melalui penyajian data tersebut, maka data terorganisasikan, tersusun dalam pola hubungan, sehingga akan semakin mudah dipahami. Ketiga, tahap conclusion drawing/verification dari hasil penelitian. Setelah melihat data hasil penelitian dalam bentuk tabel, peneliti mencari dan menghubungkan antara data hasil penelitian di lapangan dengan berbagai teori-teori dan bukti pendukung. Sehingga, dari data tersebut peneliti berhasil untuk menarik kesimpulan dari hasil penelitian yang telah dilakukan. 


\section{HASIL DAN PEMBAHASAN}

HASIL

Sesuai dengan tujuan penelitian, yaitu untuk mendeskripsikan peran yang ditunjukkan oleh kelompok teman sebaya dan mengidentifikasi faktor-faktor penyebab yang mempengaruhi pengambilan keputusan karier siswa peneliti merangkum data hasil penelitian ke dalam tabel.

Tabel I. Peran Teman Sebaya

\begin{tabular}{cccc}
\hline Peran teman sebaya & Bentuk peran \\
\hline & Perasaan nyaman dan aman ketika
\end{tabular}

Dukungan sosial, moral dan emosional didengarkan, ketika ingin bercerita teman sebaya selalu terbuka, terjaga semua rahasia yang tidak bisa diungkapkan kepada orangtua dan merasa lebih disupport oleh teman sebaya

Teman sebaya selalu mendukung, tidak

Kebebasan berpendapat, bertindak atau menemukan identitas diri memaksakan keinginannya dan tidak melarang setiap pilihan keputusan karier bahkan banyak memberikan solusi untuk informasi yang salah maupun kurang Siswa menjadi orang lebih paham akan keputusan karier yang dipilih, menjadi paham akan kemampuan yang dimiliki,

Sebagai agen sosialisasi merasa menjadi pribadi yang lebih baik, menjadi pribadi yang lebih percaya diri, mudah bergaul, berani berbicara di depan orang banyak dan memiliki teman yang banyak

Sebagai role model Tidak ditemukan pada teman sebaya Teman sebaya membuat tebak-tebakan soal tes ujian masuk perguruan tinggi ataupun

Mengembangkan keterampilan melalui pesan singkat potongan ayat alqur'an yang terkadang dikirimkan oleh teman sebaya

Dari tabel I menjelaskan bahwa dari kelima peran teman sebaya hanya empat peran yang ditunjukkan, yaitu dukungan sosial, moral dan emosional; kebebasan berpendapat, bertindak atau menemukan identitas diri; sebagai agen sosialisasi; dan mengembangkan keterampilan. Sedangkan pada peran sebagai role model tidak ditunjukkan oleh teman sebaya.

Selanjutnya, berdasarkan hasil di lapangan faktor-faktor yang sangat berpengaruh dalam keputusan karier siswa adalah faktor kondisi lingkungan. Faktor yang berasal dari faktor belajar tidak terlalu mempengaruhi. Sedangkan untuk faktor genetik dan keterampilan menghadapi tugas tidak mempengaruhi keputusan karier sama sekali.

\section{PEMBAHASAN}

\section{Peran Teman Sebaya}

Berdasarkan data hasil penelitian yang telah dilakukan, sesuai dengan indikator peran teman sebaya terdapat lima peran, yaitu 1) dukungan sosial, moral dan emosional; 
2) kebebasan berpendapat, bertindak atau menemukan identitas diri; 3) sebagai agen sosialisasi; 4) sebagai role model; 5) mengembangkan keterampilan. Dari kelima peran tersebut, teman sebaya mempengaruhi pengambilan keputusan karier.

Dukungan teman sebaya sangat berpengaruh dalam kematangan karier. Dukungan teman sebaya yang ditunjukkan dalam kategori positif dapat menunjukkan bentuk dukungan teman sebaya seperti pemberian motivasi, pernyataan setuju atau tanggapan positif, meminjamkan barang (handphone atau laptop), dan pemberian informasi pekerjaan tersebut dapat memberikan makna positif atau bermanfaat dalam mencapai karier yang diinginkannya (Hendayani \& Abdullah, 2018). Selain itu, dukungan yang diberikan juga bisa berupa dukungan informational yang dapat menurunkan kesulitan pengambilan keputusan kariernya. Sehingga, teman yang dipilih oleh siswa mungkin dapat bersifat positif atau negatif bagi karier siswa, memiliki teman yang tepat dapat menjadi penting untuk keberhasilan akademik, untuk perencanaan karier siswa dan tekanan psikologis (Fadhillah \& Yudiana, 2020).

Pada peran pertama yaitu dukungan sosial, moral dan emosional, subyek penelitian mendapatkan dukungan yang ditunjukkan oleh teman sebaya seperti perasaan nyaman dan aman ketika bercerita; selalu diperhatikan; selalu didengarkan; ketika ingin bercerita teman sebaya selalu terbuka; terjaga semua rahasia yang tidak bisa diungkapkan kepada orangtua dan merasa lebih disupport oleh teman sebaya. Dengan adanya dukungandukungan yang ditunjukkan oleh teman sebaya, siswa menjadi lebih terbuka; merasa senang dan lebih nyaman ketika bercerita mengenai permasalahan karier yang dialami. Sehingga, ketika ingin menyelesaikan permasalahan tersebut siswa akan berusaha untuk meminta bantuan dengan teman sebaya dan saling berdiskusi untuk solusi terbaik yang sesuai dengan yang diinginkan hingga akhirnya siswa mengetahui keputusan kariernya di masa depan.

Teman sebaya dapat dijadikan sumber rasa nyaman dan aman karena teman sebaya bisa menjadi sebuah kelompok tempat mereka dapat belajar bersama, aman dari anakanak berandalan; bahkan pada saat memasuki masa pubertas, teman sebaya sering kali menjadi andalan, mengalahkan orang tua sendiri, terutama ketika mengalami masa krisis atau kebingungan (Susanto, 2016). Adanya dukungan dari teman sebaya bisa dilihat dari banyaknya kontak sosial yang terjadi atau yang dilakukan individu dalam menjalin hubungan dengan sumber-sumber yang ada di lingkungan (Baron \& Byrne, 2005). Maka dari itu, tingkat keakraban yang terjalin antara siswa dengan teman sebaya juga sangat berpengaruh dalam keputusan karier. Semakin tinggi tingkat keakrabannya maka akan berpengaruh dalam keputusan karier.

Selanjutnya, peran kedua yaitu kebebasan berpendapat, bertindak atau menemukan identitas diri. Pada peran ini teman sebaya selalu mendukung dan tidak melarang setiap pilihan keputusan karier yang akan dipilih bahkan teman sebaya banyak memberikan solusi untuk informasi yang salah maupun kurang. Selain itu, teman sebaya tidak memaksakan keinginannya agar siswa mengikutinya karena bagi siswa perlu adanya pertimbangan untuk memilih yang sesuai.

Melalui peran ini, teman sebaya memberikan kebebasan bagi siswa untuk lebih memahami keinginannya dalam karier. Siswa bebas ingin mengutarakan berbagai pendapatnya selama berdiskusi, mengambil keputusan karier tertentu bahkan bebas untuk menolak setiap saran yang diberikan. Teman sebaya hanya memberikan bantuan dan mengarahkan, tidak memaksa untuk menjadi yang sesuai dikatakannya.

Memang, anak-anak pada usia remaja sering berubah-ubah dalam pekerjaan atau studi lanjut dan tidak memiliki arah dalam eksplorasi dan perencanaan karier (Santrock, 2003). Tetapi, berdasarkan peran yang ditunjukkan oleh teman sebaya yaitu peran 
kebebasan berpendapat, bertindak atau menemukan identitas diri, teman sebaya mengarahkan dan memberikan bantuan untuk lebih memahami keputusan karier. Sehingga, pada akhirnya siswa bebas untuk memutuskan dari berbagai alternatif-alternatif yang ada sebagai pilihan karier dimasa depan.

Teman sebaya juga bisa memberikan perubahan pada dalam diri individu. Selama berteman akrab antara satu sama lain, teman sebaya membantu membentuk perilaku dan keyakinan anak (Ormord, 2009). Peran ini disebut sebagai agen sosialisasi. Sebagai agen sosialisasi, teman sebaya membawa perubahan-perubahan tertentu. Misalnya siswa menjadi orang lebih paham akan keputusan karier yang dipilih, menjadi paham akan kemampuan yang dimiliki, merasa menjadi pribadi yang lebih baik, menjadi pribadi yang lebih percaya diri, mudah bergaul, berani berbicara di depan orang banyak dan memiliki teman yang banyak.

Siswa yang saling berinteraksi dengan teman sebaya akan berkesempatan untuk: 1) melatih atau belajar berinteraksi dengan orang lain, 2) melatih dalam mengontrol tingkah laku terhadap orang lain, 3) mengembangkan keterampilan dan kemampuan yang dimiliki serta minatnya. 4) saling bertukar perasaan dan masalah yang dialaminya (Alhafid \& Nora, 2020). Melalui interaksi tersebut siswa mendapat kesempatan untuk belajar menunjukkan kemampuan yang dimiliki ataupun membentuk kepribadian yang baru.

Oleh karena itu, melalui interaksi yang terjadi menimbulkan suatu perubahan yang ada di dalam diri siswa mengenai keputusan karier. Hal ini menunjukkan bahwa teman yang memberikan perubahan positif maka bisa memberikan pengaruh yang baik sehingga keputusan karier yang diambil akan baik pula. Sebaliknya, jika perubahan yang diberikan oleh teman sebaya adalah perubahan yang buruk maka bisa memberikan pengaruh yang buruk juga baik kepribadian maupun keputusan karier.

Seperti yang bisa dilihat pada hasil yang diperoleh peneliti, hal inilah yang terjadi pada subyek dan teman sebaya. Interaksi antara subyek dengan teman sebaya menunjukkan perubahan-perubahan di atas, seperti lebih paham akan keputusan karier yang dipilih, menjadi paham akan kemampuan yang dimiliki, merasa menjadi pribadi yang lebih baik, menjadi pribadi yang lebih percaya diri, mudah bergaul, berani berbicara di depan orang banyak dan memiliki teman yang banyak. Baik subyek maupun teman sebaya merasa selama berteman akrab banyak perubahan-perubahan positif sehingga membentuk suatu kepribadian yang lebih baik.

Selain itu, teman sebaya juga bisa dijadikan sebagai contoh dalam keputusan karier. Peran ini disebut sebagai role model. Berdasarkan hasil data penelitian, peran ini tidak ditemukan pada teman sebaya. Alasannya dikarenakan terdapat siswa yang bersifat egois, tidak ingin ikut-ikutan, bahkan tetap pada pilihan sendiri.

Teman sebaya sebagai model atau contoh tentang cara berperilaku terhadap teman-teman sebaya menyediakan sumber informasi dan perbandingan tentang dunia di luar keluarga. Siswa menerima umpan balik tentang kemampuan-kemampuan mereka dari kelompok teman sebaya dan belajar tentang dunia di luar keluarga mereka (Susanto, 2016).

Oleh karena itu, teman sebaya akan mendukung satu sama lain ketika temannya berperilaku dengan cara-cara yang dianggap tepat sesuai usia, jenis kelamin, atau kelompok etnik. Namun, disisi lain teman sebaya menghukum satu sama lain atas perilaku yang dianggap melanggar batas, misalnya melalui olok-olok, gossip, atau ostrasisme (pengucilan) (Ormord, 2009). Perlakuan inilah yang membuat siswa untuk takut mencontoh atau mencontek bahkan menghindari tentang cara berperilaku dari teman sebaya.

Terakhir, pada peran mengembangkan keterampilan teman sebaya membantu siswa dalam mengembangkan keterampilan untuk meningkatkan kemampuan menghapal dan 
mengingat materi ujian tes karier yang telah dipilih siswa. Ada berbagai cara yang dilakukan oleh siswa, seperti teman sebaya membuat tebak-tebakan soal tes ujian masuk perguruan tinggi ataupun melalui pesan singkat potongan ayat Al-qur'an yang terkadang dikirimkan oleh teman sebaya membantu siswa untuk selalu mengingat ayat-ayat Alqur'an untuk tes ujian masuk.

Dengan teman sebaya, siswa mengembangkan keterampilan yang diperlukan untuk bersosialisasi dan menjalin keakraban. Siswa mampu meningkatkan hubungan dengan teman, siswa mendapatkan rasa kebersamaan. Selain itu, siswa termotivasi untuk mencapai prestasi dan mendapatkan rasa identitas. Siswa juga mempelajari keterampilan kepemimpinan dan keterampilan berkomunikasi, bekerja sama, bermain peran, dan membuat atau menaati aturan (Susanto, 2016).

Oleh karena itu, jika teman sebaya memberikan bantuan seperti hal-hal yang secara nyata diperlukan oleh siswa maka bantuan tersebut dapat memberikan dukungan positif, sehingga mampu mencapai kematangan karier. Sebaliknya jika teman sebaya tidak memberikan bantuan seperti hal-hal yang secara nyata diperlukan, maka siswa akan kurang mampu mencapai kematangan karier.

\section{Faktor-Faktor yang Mempengaruhi Keputusan Karier}

Sesuai dengan indikator penelitian, terdapat empat kategori yang mempengaruhi pengambilan keputusan karier, yaitu genetik, kondisi lingkungan, faktor belajar dan keterampilan menghadapi tugas. Berdasarkan hasil penelitian, sebagian besar faktor yang mempengaruhi pengambilan keputusan karier ialah kondisi lingkungan. Faktor yang berasal dari faktor belajar tidak terlalu mempengaruhi. Sedangkan untuk faktor genetik dan keterampilan menghadapi tugas tidak mempengaruhi keputusan karier sama sekali.

Faktor kondisi lingkungan secara keseluruhan sangat mempengaruhi keputusan karier berdasarkan hasil data penelitian. Kondisi lingkungan bisa berasal dari orang tua maupun teman (Howard et al., 2010). Namun, yang paling berpengaruh berdasarkan hasil data penelitian adalah teman sebaya dikarenakan rasa kebingungan yang dialami oleh siswa. Melalui teman sebaya mereka berusaha untuk menggali berbagai informasi yang pada akhirnya akan mereka pilih sesuai dengan dirinya. Selain itu, berbagai dukungan yang diterima juga memicu mereka untuk lebih yakin akan keputusan karier yang akan dipilih.

Pengaruh teman sebaya merupakan salah satu faktor eksternal dimana teman sebaya memberikan dorongan berupa minat dalam memilih karier dimasa depan (Zulfa et al., 2018). Melalui dorongan-dorongan inilah yang mempengaruhi dalam keputusan karier. Dorongan-dorongan ini bisa diperoleh melalui peran yang ditemukan pada teman sebaya. Sesuai hasil data penelitian, dukungan yang ditemukan pada peran teman sebaya adalah dukungan sosial, moral dan emosional; kebebasan berpendapat, bertindak atau menemukan identitas diri; sebagai agen sosialisasi dan mengembangkan keterampilan.

Oleh karena itu, teman sebaya merupakan faktor kunci bagi seseorang untuk menemukan jati diri dirinya. Seseorang yang berteman dengan orang-orang yang pintar biasanya terpengaruh secara positif agar dirinya menjadi pintar, tetapi jika berteman dengan orang-orang yang suka bolos sekolah maka kemungkinan akan tertular untuk melakukan tindakan tersebut (Zulfa et al., 2018). Namun, jika dilihat berdasarkan hasil data penelitian terdapat faktor lain yang tidak terlalu mempengaruhi keputusan karier ialah faktor belajar. Siswa menganggap bahwa selama mereka memperoleh pengalaman hidup yang menarik baik di sekolah maupun di luar sekolah tidak terlalu mempengaruhi keputusan karier mereka. 
Berdasarkan hasil data penelitian, hal ini tidak sependapat dengan penelitian Rahmat et al. (2014) yang menyatakan faktor belajar berada pada kategori kedua dalam mempengaruhi keputusan karier sebesar 69,90\%. Perbedaan ini disebabkan karena pengalaman belajar yang diperoleh baik di sekolah maupun di luar sekolah hanya sebagai pengalaman belajar saja dan tidak menjadi acuan dalam keputusan karier.

Setiap orang memiliki sejarah pengalaman belajar yang unik. Melalui pengalaman belajar tersebut bisa mempengaruhi tingkah laku dan keputusan seseorang, contohnya tingkah laku pilihan karier (Brown, 2003). Tetapi, jika pengalaman belajar yang didapat tidak mendidik maka akan menghalangi pengalaman selanjutnya. Sebaliknya, pengalaman belajar yang mendidik akan mampu mendorong siswa mengembangkan perubahan secara intensional (Dharma \& Siregar, 2015).

Sehingga, pengalaman belajar yang dialami subyek baik di sekolah maupun di luar sekolah jika tidak memberikan dampak yang positif maka akan berpengaruh dalam keputusan karier. Pada akhirnya, siswa akan kesulitan untuk mengambil keputusan yang tepat terhadap alternatif-alternatif pilihan karier di masa depan. Terakhir, ada juga faktor yang tidak mempengaruhi keputusan karier sama sekali. Pertama, faktor genetik dikarenakan ketidakyakinan bahkan kurang memahami mengenai kemampuan yang telah dimiliki sejak lahir. Sehingga, menganggap semua keputusan karier berasal dari faktor lingkungan.

Faktor genetik bisa berupa wujud dan keadaan fisik (jenis kelamin ras, suku bangsa, dan karakteristik fisik) serta kemampuan khusus (intelegensi dan bakat tertentu) (Brown, 2003). Perwujudan dari faktor ini harus dipahami dengan baik agar dikembangkan dengan optimal. Maka dari itu, tidak mengherankan apabila ada seorang individu yang memiliki kemampuan khusus sama seperti yang dimiliki oleh orangtuanya. Hal ini disebabkan faktor warisan genetik yang diturunkan dari orangtuanya tersebut. Potensi dari warisan genetik inilah yang akan menjadi dasar bagi seorang individu dalam merencanakan arah pilihan kariernya (Sari et al., 2021).

Sebenarnya masing-masing individu lahir dengan potensi bawaan dari lahir berupa bakat, minat dan keterampilan khusus yang dimiliki individu tersebut. Potensi dan keterampilan khusus tersebut harus bisa dikembangkan dengan baik oleh individu (Sari et al., 2021). Akan tetapi, pemahaman yang tidak optimal akan potensi bawaan itulah yang akhirnya membuat subyek merasa faktor belajar tidak mempengaruhi keputusan karier sama sekali. Sehingga, subyek mengalami kesulitan dalam pengambilan keputusan karier.

Kedua, faktor keterampilan menghadapi tugas tidak mempengaruhi keputusan karier sama sekali dikarenakan siswa merasa hal-hal yang berkaitan dengan pengalaman belajarnya bukan merupakan suatu kelebihan yang dimiliki oleh siswa. Namun, data hasil penelitian tersebut tidak sejalan dengan hasil penelitian Rahmat et al., (2014) yang menyatakan bahwa faktor keterampilan menghadapi tugas berada pada urutan ketiga yang mempengaruhi keputusan karier siswa sebesar $68,11 \%$.

Perbedaan hasil data di atas disebabkan oleh berbagai faktor salah satunya dari faktor internal siswa itu sendiri yang masih belum memahami keterampilan untuk memutuskan karier bagi dirinya sendiri. Faktor dalam keterampilan menghadapi tugas akan diperoleh siswa jika pengalaman belajar, ciri genetik, kemampuan khusus (khusus), dan lingkungan saling berinteraksi. Sehingga, temuan penelitian ini menguatkan teori Brown (2003) bahwa siswa akan dapat menerapkan keterampilan pengambilan keputusan karier berdasarkan pengalamannya.

\section{SIMPULAN}

Setelah dilakukan penelitian di MAN Kota Singkawang dengan subyek penelitian sebanyak enam orang siswa kelas XII diperoleh bahwa terdapat beberapa peran kelompok 
teman sebaya yang ditunjukkan dalam pengambilan keputusan karier siswa MAN Kota Singkawang. Pertama, dukungan sosial, moral dan emosional berupa perasaan lebih terbuka; senang dan lebih nyaman ketika bercerita mengenai permasalahan karier yang dialami. Kedua, kebebasan berpendapat, bertindak atau menemukan identitas diri berupa memberikan bantuan dan mengarahkan, tidak memaksa untuk menjadi yang sesuai dikatakan teman sebaya. Ketiga, sebagai agen sosialisasi berupa lebih paham akan keputusan karier yang dipilih, menjadi paham akan kemampuan yang dimiliki, merasa menjadi pribadi yang lebih baik, menjadi pribadi yang lebih percaya diri, mudah bergaul, berani berbicara di depan orang banyak dan memiliki teman yang banyak. Keempat, mengembangkan keterampilan berupa bantuan-bantuan baik secara fisik maupun informasi yang secara nyata diperlukan oleh teman. Selain itu, faktor yang berpengaruh dalam keputusan karier ialah faktor kondisi lingkungan yang sangat berpengaruh dalam pengambilan keputusan karier. Sedangkan untuk faktor belajar tidak terlalu berpengaruh dalam pengambilan keputusan karier.

\section{UCAPAN TERIMAKASIH}

Saya ucapkan terimakasih kepada teman-teman seperjuangan, dosen pembimbing dan sahabat yang telah membantu saya selama melakukan penelitian.

\section{DAFTAR PUSTAKA}

Alhafid, A. F., \& Nora, D. (2020). Kontribusi Dukungan Sosial Orang Tua dan Peran Teman Sebaya Terhadap Hasil Belajar Sosiologi Siswa kelas X dan XI di SMA Negeri 2 Bengkulu Selatan. Jurnal Sikola: Jurnal Kajian Pendidikan Dan Pembelajaran, 1(4), 284-300. https://doi.org/10.24036/sikola.v1i4.53

Aminnurrohim, A. W., Saraswati, S., \& Kurniawan, K. (2014). Survei Faktor-Faktor Penghambat Perencanaan Karir Siswa. Jurnal Bimbingan Dan Konseling, 3(2), 57-63.

Amsanah, S. (2018). Efektivitas Layanan Informasi Untuk Meningkatkan Pemilihan Karir Peserta Didik Kelas XII SMK Negeri 5 Bandar Lampung Tahun Pelajaran 2018/2019 (Vol. 11, Issue 1). (Doctoral Dissertation, Universitas Islam Negeri Raden Intan).

Baron, R. A., \& Byrne, D. (2005). Psikologi Sosial Edisi Kesepuluh Jilid 2. Jakarta: Erlangga.

Brown, D. (2003). Career Information, Career Counseling, and Career Development (8th). Boston: University of Nort Carolina At Chapel Hill.

Dharma, S., \& Siregar, R. (2015). Membangun Pengalaman Belajar Kewarganegaraan Melalui Model Pembelajaran Project Citizen Pada Siswa. Jupiis: Jurnal Pendidikan Ilmu-Ilmu Sosial, 7(1), 100. https://doi.org/10.24114/jupiis.v7i1.2303

Fadhillah, S. H., \& Yudiana, W. (2020). Kesulitan Pengambilan Keputusan Karier Pada Siswa Di Daerah Rural: Bagaimana Peran Dukungan Sosial? Persona:Jurnal Psikologi Indonesia, 9(2), 229-248. https://doi.org/10.30996/persona.v9i2.3375

Hendayani, N., \& Abdullah, S. M. (2018). Dukungan Teman Sebaya dan Kematangan Karier Mahasiswa Tingkat Akhir. Jurnal Ilmiah Psikologi Terapan, 6(1), 28. https://doi.org/10.22219/jipt.v6i1.5189 
Howard, K. A. S., Budge, S. L., Gutierrez, B., Owen, A. D., Lemke, N., Jones, J. E., \& Higgins, K. (2010). Future Plans of Urban Youth: Influences, Perceived Barriers, and Coping Strategies. Journal of Career Development, 37(4), 655-676. https://doi.org/10.1177/0894845309358999

Hurlock, E. B. (2006). Psikologi Perkembangan. Jakarta: Erlangga.

Imbellone, A., \& Laghi, F. (2016). The Role of Time Perspective in Social Cognitive Career Theory of Interests. Time and Society, 25(2), 334-354. https://doi.org/10.1177/0961463X15577263

Istifarani, F. (2016). Pengaruh Dukungan Keluarga Terhadap Pengambilan Keputusan Karir Siswa Kelas X di SMK Negeri 1 Depok. Jurnal Riset Mahasiswa Bimbingan Dan Konseling, 5(5).

Kristiono, W. S. (2018). Peran Kelompok Teman Sebaya Dalam Menentukan Pengambilan Keputusan Karir Pada Siswa Kelas XI Di SMK Negeri 7 Yogyakarta. Jurnal Riset Mahasiswa Bimbingan Dan Konseling, 4(10), 604-614.

Marliyah, L., Dewi, F. I. R., \& Suyasa, P. T. (2004). Persepsi Terhadap Dukungan Orangtua dan Pembuatan Keputusan Karir Remaja. Jurnal Provitae, 1(1), 59-82.

Moleong, J. L. (2016). Metodologi Penelitian Kualitatif Edisi Revisi. Bandung: Remaja Rosdakarya.

Ormord, J. E. (2009). Psikologi Pendidikan: Membantu Siswa Tumbuh dan Berkembang Jilid I. Jakarta: Erlangga.

Prastya, A. (2016). Bimbingan dan Konseling Karir dengan Pendekatan Social Learning Krumboltz dalam Menentukan Pemilihan Karir Seorang Siswa Kelas XI di MA Bilingual Krian Sidoarjo. UIN Sunan Ampel Surabaya.

Rahmat, D., Wahyuni, E., \& Herdi, H. (2014). Faktor-Faktor yang Mempengaruhi Pengambilan Keputusan Karir Mahasiswa Jurusan Bimbingan dan Konseling. Insight: Jurnal Bimbingan Konseling, 3(2), 20. https://doi.org/10.21009/insight.032.04

Republik Indonesia. (2015). Undang-Undang Republik Indonesia Nomor 22 Tahun 2015 Tentang Rencana Strategis Kementerian Pendidikan dan Kebudayaan. Jakarta: Kementerian Pendidikan dan Kebudayaan.

Santrock, J. W. (2003). Psikologi Pendidikan. Jakarta: Kencana.

Santrock, J. W. (2007). Psikologi Pendidikan. Jakarta: Kencana.

Sari, A. K., Yusuf, A. M., Megaiswari, M., \& Afdhal, A. (2021). Analisis Teori Karir Krumboltz: Literature Review. Jurnal Ilmiah Bimbingan Konseling Undiksha, 12(1), 116-121. https://doi.org/10.23887/XXXXXX-XX-0000-00

Sugiyono. (2014). Metode Penelitian Pendidikan (Pendekatan Kuantitatif, Kualitatif, dan $R \& D)$. Bandung: Alfabeta.

Sugiyono. (2017). Metode Penelitian Pendidikan (Pendekatan Kuantitatif, Kualitatif, dan $R \& D)$. Bandung: Alfabeta.

Suhartono, S. (2008). Wawasan pendidikan: Sebuah pengantar pendidikan. Yogyakarta: Ar Ruzz Media.

Sukmadinata, N. S. (2011). Metode Penelitian Pendidikan. Bandung: Remaja Rosdakarya. 
Supriatna, M., \& Budiman, N. (2010). Layanan Bimbingan Karier Di Sekolah Menengah Kejuruan (E-Book). Bandung: Departemen Pendidikan Nasional Universitas Pendidikan Indonesia.

Susanto, I. (2016). Pengaruh Kelompok Teman Sebaya Terhadap Perilaku Menyimpang Peserta Didik di Sekolah (Studi Deskriptif di kelas X SMA Pasundan 3 Bandung). (Doctoral Dissertation, FKIP UNPAS).

Suwanto, I. (2018). Teknik Self Management Terhadap Kematangan Karir Siswa SMK Negeri 2 Singkawang. Jurnal Bimbingan Dan Konseling Indonesia, 3(1), 27-30.

Walgito, B. (2010). Bimbingan dan Konseling (Studi dan Karier). Yogyakarta: Andi Offset.

Zulfa, N. I., Heryaniningsih, S. M., Saputra, M. R., \& Putri, M. K. (2018). Pengaruh Teman Sebaya Terhadap Minat Melanjutkan Studi Ke Perguruan Tinggi pada Siswa SMA. Journal of Innovative Counseling: Theory, Practice \& Research, 2(2), 69-74.

\section{PROFIL SINGKAT}

Insan Suwanto, S. Pd., M. Pd. adalah Dosen Program Studi Bimbingan dan Konseling, STKIP Singkawang.

Dian Mayasari, S. Pd., M. Pd. adalah Dosen Program Studi Bimbingan dan Konseling, STKIP Singkawang.

Nurul Wulan Dhari adalah Mahasiswa Program Studi Bimbingan dan Konseling, STKIP Singkawang. 